\title{
Residual effect of KCl coated by polymeters incorporated in a corn crop
}

\author{
Efecto residual de la aplicación de KCl recubierto por polimeros en un cultivo de maíz \\ Lais Meneghini Nogueira ${ }^{1}$, Salatiér Buzetti ${ }^{1}$,Marcelo Carvalho Minhoto Teixeira Filho', \\ Fernando Shintate Galindo ${ }^{*}$, Tayene Franco Mello ${ }^{1}$
}

\begin{abstract}
The use of polymer-coated potassium fertilizers may reduce the leaching of potassium $(\mathrm{K})$ in the soil, increasing the availability of this nutrient to plants for a long period. In this context, the residual effect of doses and sources of potassium chloride (KCl) application on K nutrition, production components and corn grain yield in two sequential crops were investigated in this study. The experiment was conducted in a clayey Oxisol. The experiment was arranged in a randomized complete block design with four replicates in a $4 \times 4$ factorial scheme: four potassium doses $\left(0,40,80\right.$ and $120 \mathrm{~kg} \mathrm{ha}^{-1}$ of $\left.\mathrm{K}_{2} \mathrm{O}\right)$ and four $\mathrm{KCl}$ sources [uncoated fertilizer (conventional) and three sources of fertilizer coated with different polymers]. The $\mathrm{KCl}$ sources showed the same residual effect for most production components, leaf K content and corn grain yield in both crops. The increase of $\mathrm{K}$ fertilizer doses in the previous crop provided residual effect on the second-harvest corn crop, resulting in linear increase in leaf $\mathrm{K}$ content, weight of 100 grains and grain yield up to the dose of $77 \mathrm{~kg} \mathrm{ha}^{-1}$, whit the use of any source of $\mathrm{KCl}$.
\end{abstract}

Keywords: Zea mays $L$., fertilizer with enhanced efficiency, potassium fertilizer, grain yield.

\section{RESUMEN}

El uso de fertilizantes potásicos recubiertos con polímeros puede reducir la lixiviación de potasio $(K)$ en el suelo, poniendo a disposición del cultivo este nutriente por un mayor tiempo. Se evaluó el efecto residual de la dosis de K2O y las fuentes de cloruro de potasio $(\mathrm{KCl})$ sobre el contenido de K foliar, componentes de producción y productividad de granos de maíz en dos cultivos consecutivos. El experimento se realizó en un suelo tipo oxisol (Ferralsol) de textura arcillosa. El modelo experimental fue de bloques al azar, con cuatro repeticiones, dispuestos en esquema factorial $4 x 4$. Se aplicaron cuatro dosis de K2O (0, 40, 80 y 120 $\mathrm{kg} \mathrm{ha}^{-1}$ ) y cuatro fuentes de $\mathrm{KCl}$ (una convencional y tres recubiertas con diferentes polímeros). Las fuentes de KCl presentaron el mismo efecto residual para la mayoría de los componentes de producción, el contenido de K foliar y la productividad de los granos de maíz. El incremento de las dosis de $\mathrm{K} 2 \mathrm{O}$ en el cultivo anterior proporcionó un efecto residual en la cosecha del cultivo de maíz segundo periodo, aumentando linealmente el contenido de K foliar, la masa de 100 granos y la productividad de granos hasta la dosis de $77 \mathrm{~kg} \mathrm{ha}^{-1}$, independiente de la forma de $\mathrm{KCl}$. Sin embargo, no hubo efecto residual de dosis de K2O para productividad de granos de maíz en el segundo cultivo.

Palabras clave: Zea mays L., fertilizante de eficiencia mejorada, fertilización potásica, productividad de granos.

\section{Introduction}

Brazil is the third largest corn producer and the second largest exporter, but in order to obtain high corn grain yield it is necessary to apply high doses of fertilizers, such as nitrogen $(\mathrm{N})$ and potassium (K), mainly because soils do not supply the crop demand along its growth cycle and also due to inadequate use of liming and fertilization (Rodrigues et al., 2014).
Potassium has a great impact on crop quality, having a positive influence on the individual grain mass and the number of grains per ear. After N, K is the element absorbed in greater quantities by corn crop, for example, $30 \%$ of $\mathrm{K}$ applied is removed by grains. However, until recently the responses to $\mathrm{K}$ fertilizer obtained in field trials with corn crop were, in general, less frequent and lower than those observed for $\mathrm{P}$ and $\mathrm{N}$ due mainly to the low yield levels obtained (Rodrigues et al., 2014).

\footnotetext{
1 Department of Plant Health, Rural Engineering, and Soils, São Palo State University, Av. Brasil Sul, 830 - Centro, Ilha Solteira, SP, Brazil.

* Corresponding author: fs.galindo@yahoo.com.br
}

Fecha de Recepción: 10 de Junio, 2019.

Fecha de Aceptación: 2 de Agosto, 2019. 
Insufficient application of $\mathrm{K}$ fertilizer may lead to depletion of soil $\mathrm{K}$ reserves and excessive application can intensify leaching losses even in soils with medium and high cation exchange capacity (Ernani et al., 2007). Therefore, several economic and environmental drawbacks associated with the use of conventional fertilizers become a focus of concern worldwide (James and Sojka, 2008; Ni et al., 2009). Therefore, the correct management of potassium fertilization can minimize losses and avoid K depletion in soil (Werle et al., 2008).

Among potassium fertilizers, potassium chloride $(\mathrm{KCl})$ is the most widely used in Brazil, however, $\mathrm{K}$ losses by leaching between $50-70 \%$ have been reported in the literature ( $\mathrm{Wu}$ and Liu, 2008), mainly in sandy soils and in regions with high rainfall rates. A possible alternative to minimize the leaching of this nutrient would be the use of slow-release fertilizers (Xie et al., 2011), such as polymer-coated $\mathrm{KCl}$.

Inhibitory or stabilizing fertilizers are products that reduce nutrient losses by delaying the conversion of the original forms of the fertilizer into forms that can be easily lost (Blaylock, 2007). However, in Brazil, there is still little research with polymercoated fertilizers when compared to other countries, which makes it necessary to conduct experiments in Brazilian soil and climatic conditions, especially in regions such as cerrado, which presents great potential for grain production, such as corn. These studies are extremely important because they allow us to establish cost-benefit relationships, as well as to quantify the agronomic efficiency of fertilization, thus validating the use of this type of fertilizer (Rodrigues et al., 2013).

The use of polymer-coated $\mathrm{KCl}$ in crop production systems with annual crops may be of interest to increase the residual effect of $\mathrm{K}$ on soil, thus providing this nutrient for a longer period of time, and may even meet nutritional needs of crops in succession. The objective of this study was to evaluate the residual effect of doses and sources of potassium chloride application (uncoated or coated with different polymers) on K nutrition, production components and corn grain yield in two sequential crops.

\section{Material and Methods}

The study was conducted under no-till in an area with a two-year history in this system), in the municipality of Selvíria-MS, Brazil $\left(22^{\circ} 22\right.$ ' $\mathrm{S}$ and $51^{\circ} 22^{\prime}$ ' W, with altitude of $335 \mathrm{~m}$ ). The soil of the experimental area, according to the classification of Embrapa (2013), is a Latossolo Vermelho distrófico (Oxisol), with 420, 50 and $530 \mathrm{~g} \mathrm{~kg}^{-1}$ of sand, silt and clay, respectively. The climate, according to the classification of Köppen, is the fundamental type Aw - humid tropical with a rainy season in the summer and dry in winter, and the average annual rainfall is of $1,370 \mathrm{~mm}$. The values of rainfall, average temperature and relative air humidity recorded during the conduction of the experiment are shown in Figure 1.

The chemical characteristics of soil were determined before the installation of the experiment in 2010, according to methodology proposed by Raij et al. (2001), with the following properties, in the 0.0-0.20 m depth: $\mathrm{P}$ (resin) $=22 \mathrm{mg} \mathrm{dm}^{-3}$; organic matter $=32 \mathrm{~g} \mathrm{dm}^{-3} ; \mathrm{pH}\left(\mathrm{CaCl}_{2}\right)=5.4 ; \mathrm{K}$, $\mathrm{Ca}, \mathrm{Mg}, \mathrm{H}+\mathrm{Al}=2.2 ; 30.0 ; 16.0$ and 31.8 mmol $_{\mathrm{c}}$ $\mathrm{dm}^{-3}$, respectively and soil base saturation of $60 \%$.

The experiment was arranged in a randomized complete block design with four replicates, in a $4 \times 4$ factorial scheme: four $\mathrm{K}$ doses $(0,40,80$ and $120 \mathrm{~kg} \mathrm{ha}^{-1}$ of $\mathrm{K}_{2} \mathrm{O}$ ) and four $\mathrm{KCl}$ sources [ uncoated fertilizer (conventional) and three sources of coated fertilizer with different polymers ("plastics")]. These treatments were applied to corn sowing in the first crop (2010/11) and second crop (2011). In order to evaluate the residual effect of this potassium fertilizer on the subsequent corn crop in the first crop (2011/12) and on the second crop (2012), the sowing was carried out exactly in the sowing line of the previous corn crop. The dimensions of the plots were $5.0 \mathrm{~m}$ in length with four rows spaced $0.90 \mathrm{~m}$.

The AGROCERES AG 8088, an early cycle simple hybrid, was mechanically sow with 5.4 seeds per meter (corresponding to 55,000 plants $\mathrm{ha}^{-1}$ ) on November $06^{\text {th }}, 2011$ (First crop) and May 27th 2012 (Second crop). The soil was then irrigated using a center pivot irrigation system with application rate of $14 \mathrm{~mm}$ to promote seed germination. Seedlings emerged 5 days after sowing in both crops.

The sowing fertilization was performed with $30 \mathrm{~kg} \mathrm{ha}^{-1}$ of $\mathrm{N}$ (urea) and $100 \mathrm{~kg} \mathrm{ha}^{-1}$ of $\mathrm{P}_{2} \mathrm{O}_{5}$ (simple superphosphate), for all treatments, based on the soil analysis and the fertilization recommendation for irrigated corn (Cantarella et al., 1997). The nitrogen fertilization was applied 


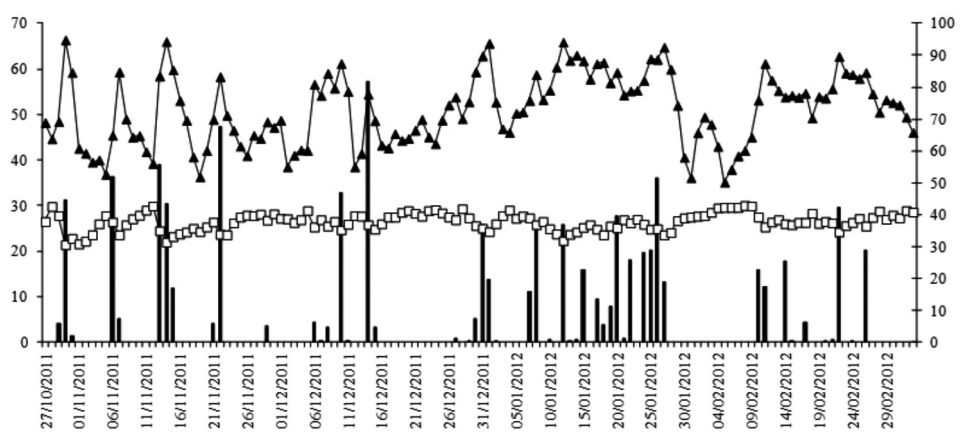

(A)

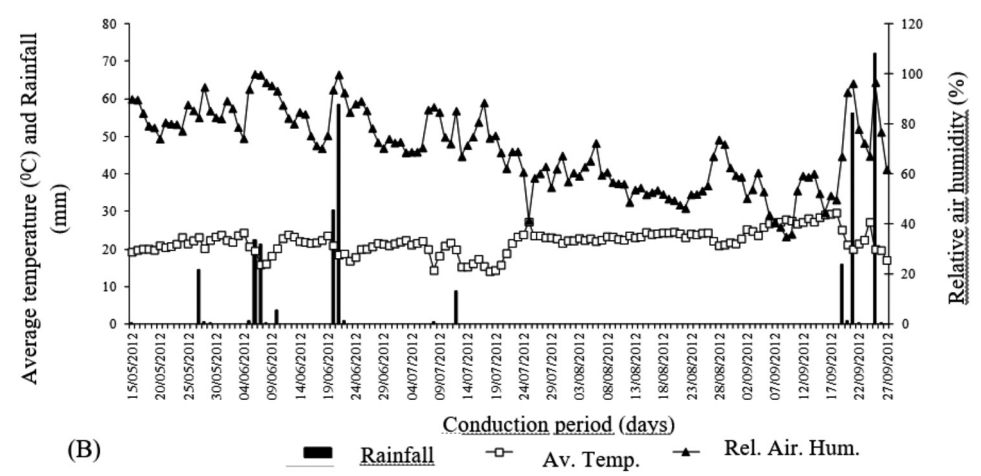

Figure 1. Rainfall, average temperature and relative air humidity recorded during the conduction of the experiments with the corn crop. First crop (A) and second crop (B). Selvíria-MS, Brazil 2011/12 and 2012.

in topdressing without incorporation at the dose of $80 \mathrm{~kg} \mathrm{ha}^{-1}$ of $\mathrm{N}$ (urea) when the plants had six completely unfolded leaves, for all treatments, positioning the manure in leading to a distance of $0.20 \mathrm{~m}$ from the crop row. The area was irrigated to minimize $\mathrm{N}$ losses by volatilization of the ammonia.

The water supply was carried out when necessary using a center pivot irrigation system. The water application rate was $14 \mathrm{~mm}$, with irrigation time of approximately 72 hours. The weed control was effected with the application of tembotrione herbicide ( $84 \mathrm{~g} \mathrm{ha}^{-1}$ active ingredient - a.i.) and atrazine (1000 $\mathrm{g} \mathrm{ha}^{-1}$ a.i.), plus the addition of vegetable oil (720 $\mathrm{g} \mathrm{ha}^{-1} \mathrm{a}$.i.), in post-emergence. Pest control was performed with methomyl (215 g $\mathrm{ha}^{-1}$ a.i.) and triflumuron $\left(24 \mathrm{~g} \mathrm{ha}^{-1}\right.$ a.i.). Corn was harvested manually at each experimental unit, in 2011/12 (First crop) at 118 days and in 2012 (Second crop) at 128 days, after the emergence of the plants.

The following evaluations were carried out: a) leaf $\mathrm{K}$ content, with the collection of 20-leaf middle third of the main stalk insertion in the female flowering of the plants, according to the methodology described in Cantarella et al. (1997) and determined in the laboratory following the methodology of Malavolta et al. (1997); b) stalk diameter was measured in the second internode, using a manual caliper; c) height of first ear insertion; d) plant height defined as being at distance (m) from the soil level to the apex of the corn tassel; e) number of grains per row; $f$ ) number of rows per ear; g) mass of 100 grains, determined in a precision scale of $0.01 \mathrm{~g}$, and $\mathrm{h}$ ) grain yield, determined by the collection of the corn ears contained in the two central rows of each plot. The material was subjected to drying in full sun and after the mechanical track, the grains were quantified and the data transformed in $\mathrm{kg} \mathrm{ha}^{-1}$, at $13 \%$ humidity (wet basis).

The evaluated traits were submitted to analysis of variance (test F) and the means of the $\mathrm{KCl}$ sources were compared by the Tukey test at $5 \%$ probability level and regression analysis was used for the $\mathrm{K}$ fertilizer doses, and significant equations (F-test; 
$\mathrm{p} \leq 0.05$ ) with the highest coefficients of determination were adjusted. The analyses were performed using the SISVAR program (Ferreira, 2011).

\section{Results and discussion}

The $\mathrm{KCl}$ sources were not different for stalk diameter, plant height, height of first ear insertion, leaf $\mathrm{K}$ content, number of grains per row and rows per ear, mass of 100 grains, and corn grain yield in the 2011/12 harvest (Tables 1 and 2). In the 2012 harvest, similar results were obtained in the assessments of stalk diameter, height of first ear insertion, leaf $\mathrm{K}$ content, number of grains per row and rows per ear and corn grain yield (Tables 1 and 2).

In the 2012 harvest, $\mathrm{KCl}$ coated with polymer 0057 provided higher plant height compared to polymer 0047, although not differing from $\mathrm{KCl}$ coated with polymer 0048 and conventional $\mathrm{KCl}$ (Table 1). In turn, $\mathrm{KCl}$ coated with polymer 0048 provided a larger mass of 100 grains than conventional $\mathrm{KCl}(0045)$ and $\mathrm{KCl}$ coated by polymer 0057 (Table 2), thus demonstrating that the coated $\mathrm{KCl}$ did not overlap with conventional $\mathrm{KCl}$ in terms of residual effect on subsequent crop cultivation.

According to Rodrigues et al. (2014), the responses of improved efficiency fertilizers depend on the microbial action; the chemically altered ones will convert part of the nutrients into insoluble forms that will be available to the plants gradually; while the coated or encapsulated, which were used in this research, consist of soluble compounds surrounded by a water-permeable resin that will regulate the nutrient delivery process. Therefore, the release will depend on the temperature and humidity of the soil. It is noteworthy that the rates of release and dissolution of water-soluble fertilizers also depend on the coating materials (Jarosiewicz and Tomaszewska, 2003).

In addition, the thickness and chemical nature of the coating resin, the amount of microcracks on its surface and the size of the fertilizer granules determine the release rate of nutrients over time (Rodrigues et al., 2013). Therefore, the types of polymers used as a coating of $\mathrm{KCl}$ were not efficient in the gradual release of $\mathrm{K}$, probably due to the edaphoclimatic conditions of the region, which presents high temperatures (Figure 1), clay soil and high microbial activity, which may have favored the rapid degradation of these coating polymers in addition to the fact that the crop was irrigated, which may have attenuated the release of $\mathrm{K}$ as a function of soil moisture, since $\mathrm{KCl}$ is a high water-soluble salt (58\% solubility), and can be easily leached (Leal et al., 2015).

Table 1. Stem diameter, plant height, height of insertion pin and $\mathrm{K}$ foliar content in function of the residual effect of forms of $\mathrm{KCl}$ and doses of potash. Selvíria - MS, Brazil, 2011/12 and 2012.

\begin{tabular}{|c|c|c|c|c|c|c|c|c|}
\hline \multirow[t]{2}{*}{ Treatment } & \multicolumn{2}{|c|}{$\begin{array}{l}\text { Stem diameter } \\
(\mathrm{cm})\end{array}$} & \multicolumn{2}{|c|}{$\begin{array}{l}\text { Plant height } \\
\text { (m) }\end{array}$} & \multicolumn{2}{|c|}{$\begin{array}{c}\text { Height of } \\
\text { insertion pin (m) }\end{array}$} & \multicolumn{2}{|c|}{$\begin{array}{l}\text { K foliar content } \\
\text { ( } \mathrm{g} \mathrm{kg}^{-1} \text { D.M.) }\end{array}$} \\
\hline & $2011 / 12$ & 2012 & $2011 / 12$ & 2012 & $2011 / 12$ & 2012 & $2011 / 12$ & 2012 \\
\hline \multicolumn{9}{|c|}{$\mathrm{KCl}$ forms } \\
\hline $0045^{(1)}$ & $2.04 \mathrm{a}$ & $2.07 \mathrm{a}$ & $2.58 \mathrm{a}$ & $2.60 \mathrm{ab}$ & $1.14 \mathrm{a}$ & $1.14 \mathrm{a}$ & $16.65 \mathrm{a}$ & $15.31 \mathrm{a}$ \\
\hline 0048 & $2.05 \mathrm{a}$ & $2.08 \mathrm{a}$ & $2.59 \mathrm{a}$ & $2.59 \mathrm{ab}$ & $1.16 \mathrm{a}$ & $1.17 \mathrm{a}$ & $15.83 \mathrm{a}$ & $15.00 \mathrm{a}$ \\
\hline 0057 & $2.06 \mathrm{a}$ & $2.08 \mathrm{a}$ & $2.55 \mathrm{a}$ & $2.62 \mathrm{a}$ & $1.13 \mathrm{a}$ & $1.18 \mathrm{a}$ & $15.84 \mathrm{a}$ & $14.25 \mathrm{a}$ \\
\hline 0047 & $2.08 \mathrm{a}$ & $2.13 \mathrm{a}$ & $2.59 \mathrm{a}$ & $2.54 \mathrm{~b}$ & $1.13 \mathrm{a}$ & $1.21 \mathrm{a}$ & $16.21 \mathrm{a}$ & $15.50 \mathrm{a}$ \\
\hline L.S.D. (5\%) & 0.20 & 0.18 & 0.09 & 0.07 & 0.07 & 0.15 & 1.95 & 0.97 \\
\hline \multicolumn{9}{|c|}{$\mathrm{K}_{2} \mathrm{O}$ doses $\left(\mathrm{kg} \mathrm{ha}^{-1}\right)$} \\
\hline 0 & 2.04 & 2.10 & 2.60 & 2.59 & 1.12 & 1.17 & 15.25 & 16.00 \\
\hline 40 & 2.02 & 2.03 & 2.59 & 2.60 & 1.17 & 1.22 & 16.43 & 14.93 \\
\hline 80 & 2.15 & 2.16 & 2.58 & 2.60 & 1.15 & 1.16 & 16.31 & 14.87 \\
\hline 120 & 2.06 & 2.07 & 2.57 & 2.57 & 1.13 & 1.16 & 16.46 & 13.75 \\
\hline C.V. $(\%)$ & 10.15 & 9.14 & 3.61 & 3.18 & 6.73 & 13.31 & 6.02 & 4.53 \\
\hline Overall Mean & 2.06 & 2.09 & 2.58 & 2.59 & 1.14 & 1.18 & 16.11 & 15.01 \\
\hline
\end{tabular}

(1) The code 0045 refers to uncoated potassium chloride and the others to potassium chloride with the coatings.

Means followed by letters equal, in the column, do not differ among themselves by the Tukey test, at a 5\% probability level. 
Table 2. Number of grains per row, number of rows per spike, mass of 100 grains and corn grain yield in function of the residual effect of forms of KCl and doses of potash. Selvíria - MS, Brazil, 2011/12 and 2012.

\begin{tabular}{|c|c|c|c|c|c|c|c|c|}
\hline \multirow[t]{2}{*}{ Treatment } & \multicolumn{2}{|c|}{$\begin{array}{l}\text { Number of } \\
\text { grains per row }\end{array}$} & \multicolumn{2}{|c|}{$\begin{array}{l}\text { Number of } \\
\text { rows per spike }\end{array}$} & \multicolumn{2}{|c|}{$\begin{array}{c}\text { Mass of } 100 \text { grains } \\
(\mathrm{g})\end{array}$} & \multicolumn{2}{|c|}{$\begin{array}{l}\text { Grain Yield } \\
\left(\mathrm{kg} \mathrm{ha}^{-1}\right)\end{array}$} \\
\hline & $2011 / 12$ & 2012 & 2011/12 & 2012 & $2011 / 12$ & 2012 & $2011 / 12$ & 2012 \\
\hline \multicolumn{9}{|c|}{$\mathrm{KCl}$ forms } \\
\hline $0045^{(1)}$ & $36.6 \mathrm{a}$ & $36.6 \mathrm{a}$ & $18.0 \mathrm{a}$ & $16.65 \mathrm{a}$ & $29.36 \mathrm{a}$ & $25.06 \mathrm{~b}$ & $92.29 \mathrm{a}$ & $73.37 \mathrm{a}$ \\
\hline 0048 & $37.1 \mathrm{a}$ & $37.1 \mathrm{a}$ & $18.1 \mathrm{a}$ & $17.05 \mathrm{a}$ & $29.55 \mathrm{a}$ & $27.16 \mathrm{a}$ & $92.94 \mathrm{a}$ & $70.62 \mathrm{a}$ \\
\hline 0057 & $36.8 \mathrm{a}$ & $36.8 \mathrm{a}$ & $18.1 \mathrm{a}$ & $16.93 \mathrm{a}$ & $29.09 \mathrm{a}$ & $25.12 \mathrm{~b}$ & $94.86 \mathrm{a}$ & $72.65 \mathrm{a}$ \\
\hline 0047 & $36.5 \mathrm{a}$ & $36.5 \mathrm{a}$ & $18.1 \mathrm{a}$ & $16.98 \mathrm{a}$ & 28.99 a & $25.98 \mathrm{ab}$ & $95.11 \mathrm{a}$ & $69.87 \mathrm{a}$ \\
\hline L.S.D. $(5 \%)$ & 1.4 & 1.4 & 0.7 & 0.69 & 1.14 & 1.81 & 7.30 & 9.66 \\
\hline \multicolumn{9}{|c|}{$\mathrm{K}_{2} \mathrm{O}$ doses $\left(\mathrm{kg} \mathrm{ha}^{-1}\right)$} \\
\hline 0 & 37.0 & 34.35 & 18.1 & 16.60 & 28.74 & 24.81 & 82.25 & 70.18 \\
\hline 40 & 37.3 & 32.55 & 18.1 & 17.08 & 29.29 & 26.24 & 97.25 & 72.40 \\
\hline 80 & 36.0 & 30.94 & 18.0 & 17.08 & 29.19 & 25.83 & 100.35 & 71.10 \\
\hline 120 & 36.7 & 31.51 & 18.1 & 16.85 & 29.77 & 26.44 & 95.36 & 72.83 \\
\hline C.V. $(\%)$ & 4.05 & 7.32 & 4.36 & 4.32 & 4.12 & 7.44 & 8.25 & 14.30 \\
\hline Overall Mean & 36.8 & 32.34 & 18.1 & 16.90 & 29.25 & 25.83 & 93.80 & 71.63 \\
\hline
\end{tabular}

(1) The code 0045 refers to uncoated potassium chloride and the others to potassium chloride with the coatings.

Means followed by letters equal, in the column, do not differ among themselves by the Tukey test, at a 5\% probability level.
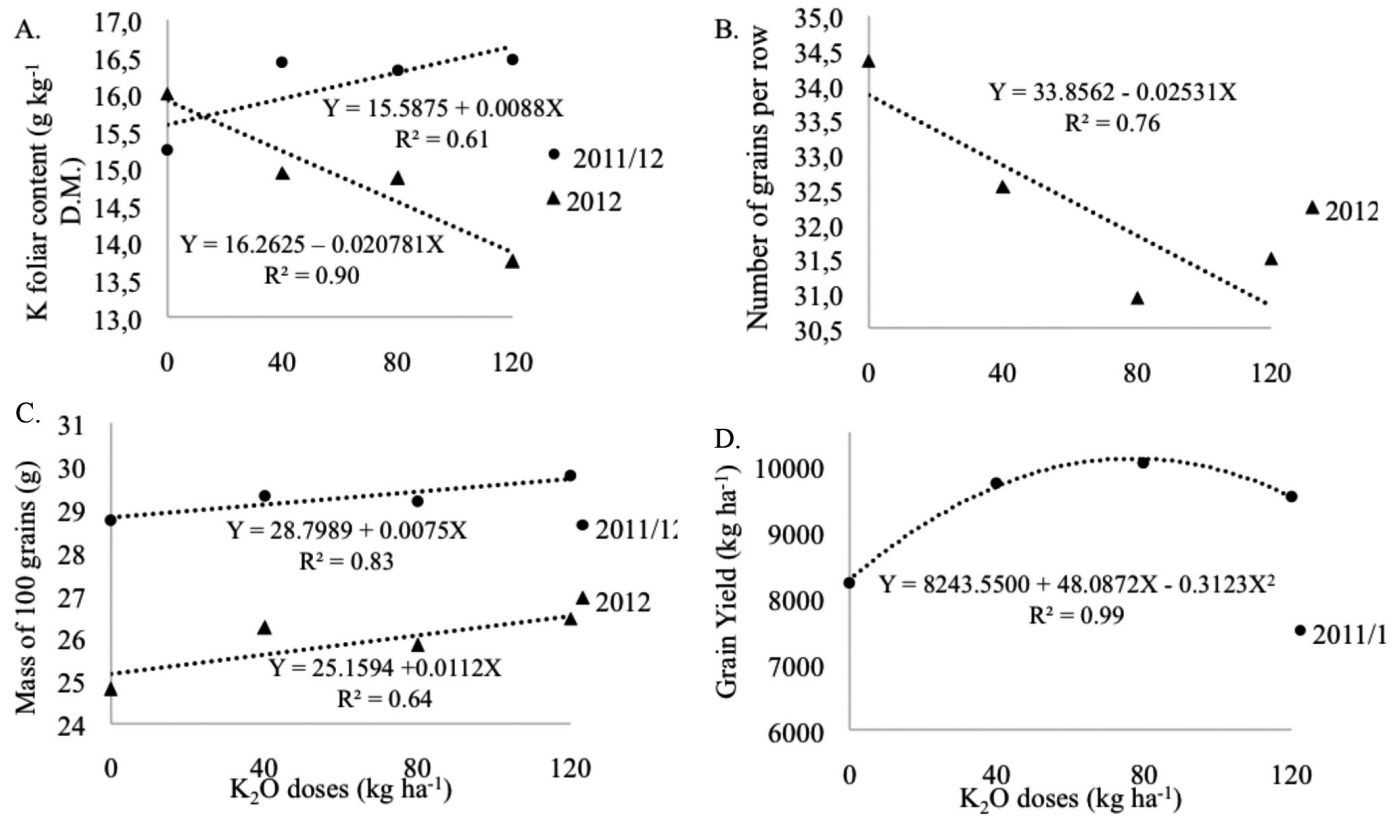

Figure 2. K foliar content, 2011/2012 and 2012 crops (A), number of grains per row, 2012 crop (B), mass of 100 grains, 2011/2012 and 2012 crops (C), corn grain yield, 2011/2012 crop (D) in function of $\mathrm{K}_{2} \mathrm{O}$ doses. Selvíria - MS, Brazil.

This can be confirmed by the similar leaf $\mathrm{K}$ contents obtained for the $\mathrm{KCl}$ sources, in both crop harvest (Table 1), which were below the appropriate range for corn (17 to $35 \mathrm{~g} \mathrm{~kg}^{-1}$ of $\mathrm{K}$ in the dry matter), in relation to that described by Cantarella et al. (1997) irrespective of the K dose applied, and although irrigation was performed to minimize the negative effect of water deficit 
on plant development, the water rate applied of $14 \mathrm{~mm}$ and the irrigation shift of approximately 72 hours would not be sufficient to promote the leaching of $\mathrm{K}$ causing deficiency in the nutrition of corn crop with this nutrient.

The results obtained corroborate with Valderrama et al. (2011) and Rodrigues et al. (2014), evaluating the production components and corn grain yield under the same Cerrado soil conditions, also found that the polymer-coated $\mathrm{KCl}$ did not stand out in relation to the conventional $\mathrm{KCl}$ when applied to the sowing and in the same crop. Similarly, Rodrigues et al. (2013) found that polymer-coated $\mathrm{KCl}$ had the same residual effect as conventional $\mathrm{KCl}$ for leaf $\mathrm{K}$ contents, production components and grain yield in irrigated common bean crop in Cerrado.

Gazola et al. (2013) reported that monoammonium-phosphate (MAP) fertilizer coated with polymers provide the same residual effect of the conventional MAP, for production components and corn grain yield in irrigated crop diverging from the results of Guareschi et al. (2011), who working with KCI coated with polymers which have found better plant nutrition when the fertilizer was applied in advance in a Oxisol with haul application of polymercoated $\mathrm{KCl}$, and further dry matter yield, number of pods per plant and soybean yield compared to conventional $\mathrm{KCl}$, and Leal et al. (2015), who found by evaluating the conventional $\mathrm{KCl}$ application in topdressing and three types encapsulated $\mathrm{KCl}$ in soybean crop, greater efficiency of $\mathrm{K}$ fertilizer with $\mathrm{KCl}$ coated with polymers.

The best plant performance when applying these fertilizers is due to the regular and continuous supply of nutrients to the plants and reduction of $\mathrm{K}$ losses by leaching. The highest rainfall rate in Rio Verde (GO) and Água Clara (MS) regions, linked to lower temperatures compared to the region of Selvíria (MS), where the present study was conducted, were possibly the limiting factors in the slow, regular and continuous release of the coated $\mathrm{KCl}$, culminating in the reduction of $\mathrm{K}$ losses by leaching.

Regarding the residual $\mathrm{K}$ doses, the increase resulted in higher leaf $\mathrm{K}$ content, mass of 100 grains and corn grain yield in the 2011/12 harvest. There was an adjustment of increasing linear function for leaf $\mathrm{K}$ content and mass of 100 grains and adjusted the quadratic function for grain yield up to the dose of $77 \mathrm{~kg} \mathrm{ha}^{-1}$ of $\mathrm{K}_{2} \mathrm{O}$ (Tables 1 and 2; and Figures
2A, 2C and 2D), regardless of $\mathrm{KCl}$ source applied in the previous crop. With this estimated dose, a grain yield of $10,095 \mathrm{~kg} \mathrm{ha}^{-1}$ was obtained, which corresponds to an increase of $23 \%$ in relation to the control (without application of $\mathrm{K}$ ), thus demonstrating the feasibility of taking advantage of the residual $\mathrm{K}$ fertilization in subsequent cultivation. Rodrigues et al. (2013) evaluating the residual effect of $\mathrm{KCl}$ doses applied in the corn crop, also verified a positive response, but with linear adjustment for irrigated common beans.

On the other hand, in second-harvest corn crop no effect of $\mathrm{K}$ doses was observed in most of the production components and grain yield (Tables 1 and 2), which may be due to the higher $\mathrm{K}$ export by grains infers in a lower $\mathrm{K}$ supply of soil to the plants, since $\mathrm{K}$ contents in the leaves decreased with increasing doses of this nutrient (Figure 2A), thus reducing the number of rows (Figure $2 \mathrm{~B}$ ) and grains per ear, and consequently, an increase in mass of 100 grains (Figure 2C). However, it was $3.4 \mathrm{~g}$ lower when compared to the corn crop (Table 2). According to Büll (1993), K has an impact on crop quality and positive influence on individual grain mass and number of grains per ear.

Gommers et al. (2005) state that there are greater absorption and accumulation of $\mathrm{K}$ in the plants with the increase of $\mathrm{K}$ doses, corroborating with the results obtained for the corn crop. On the other hand, according to Borkert et al. (1997), K content in leaves smaller than $15.5 \mathrm{~g} \mathrm{~kg}^{-1}$ decreases corn grain yield, which explains the lower yields verified for the second harvest corn, which are not common in this region when irrigation is done, since at this time of year the nocturnal temperatures are lower and favor the accumulation of carbohydrates of this plant $\mathrm{C} 4$.

According to Kaminski et al. (2007) and Rosolem et al. (2012), the exhaustion of available $\mathrm{K}$ forms of soil during the development of crop impairs plant nutrition and that the K supply capacity depends more on the newly added $\mathrm{K}$ than on the $\mathrm{K}$ fertilization historic. However, Rosolem et al. (2012) also verified that the residual $\mathrm{K}$ of previous fertilizations increased the $\mathrm{K}$ content absorbed and accumulated in the Brachiaria ruziziensis plants.

According to Brunetto et al. (2005), several studies indicated that the responses of numerous agricultural crops to $\mathrm{K}$ fertilization were low when the exchangeable $\mathrm{K}$ contents in the arable layer $(0$ to $20 \mathrm{~cm})$ of the soils were larger than 1.5 to $2 \mathrm{mmol}_{\mathrm{c}} \mathrm{dm}^{-3}$, mainly in management 
conditions that favored the increase of $\mathrm{K}$, as in the no-tillage system for example, and/or in soils with high concentration of primary and secondary minerals rich in $\mathrm{K}$ minerals. However, Kaminski et al. (2007) and Fraga et al. (2009), reported accumulation of $\mathrm{K}$ in plants due to the residual effect and/or potassium fertilization in soils with low $\mathrm{K}$ contents. In the present study, there was an average $\mathrm{K}$ content $\left(2.2 \mathrm{mmol}_{\mathrm{c}} \mathrm{dm}^{-3}\right)$.

In general, the utilization of residual $\mathrm{K}$ fertilization of corn crop seems to be feasible for only a subsequent crop, under the edaphoclimatic conditions studied, whose soil K content was adequate (average content). However, the nonapplication of $\mathrm{K}$ fertilizer in the following crops can lead to the depletion of soil reserves, with negative effects on crop nutrition and grain yield.

\section{Conclusions}

The polymer-coated $\mathrm{KCl}$ had the same residual effect as conventional $\mathrm{KCl}$ for most of the production components, leaf $\mathrm{K}$ content and corn grain yield in first and second corn harvest.

The increase of potassium fertilizer doses in the previous crop provided residual effect on the corn second-harvest crop, resulting in linear increase in the leaf $\mathrm{K}$ content, mass of 100 grains and corn grain yield up to the dose of $77 \mathrm{~kg} \mathrm{ha}^{-1}$ of $\mathrm{K}_{2} \mathrm{O}$, regardless of $\mathrm{KCl}$ source.

In the second-harvest corn and without $\mathrm{K}$ fertilizer application, there is no residual effect of $\mathrm{K}$ doses for grain yield due to the reduction of leaf $\mathrm{K}$ content, which resulted in a decrease in the number of grains per row and ear.

\section{Literature Cited}

Blaylock, A.

2007. O futuro dos fertilizantes nitrogenados de liberação controlada. Informações Agronômicas, 120: 8-10.

Borkert, C.M.; Sfrego, G.J.; Farias, J.R.B.; Castro, C. de; Spoladori, C.L.; Tudida, F.

1997. Efeito residual da adubação potássica sobre girassol e milho, em três diferentes Latossolos Roxos. Pesquisa Agropecuária Brasileira, 32 (12): 1227-1234.

Brunetto, G.; Gatiboni, L.C.; Santos, D.R.; Saggin, A.; Kaminski, J.

2005. Nível crítico e resposta das culturas ao potássio em um Argissolo sob Sistema Plantio Direto. Revista Brasileira de Ciência do Solo, 29 (4): 561-571.

Büll, L.T.

1993. Nutrição mineral do milho. In: Büll, L.T.; Cantarella, H. (ed.). Cultura do milho: fatores que afetam a produtividade. Potafos. Piracicaba, Brazil. pp. 63-145.

Cantarella, H.; Raij, B. van; Camargo, C.E.O. 1997. Cereais. In: Raij, B. van; Cantarella, H.; Quaggio, J.A.; Furlani, A.M.C. (Eds.) Recomendações de calagem e adubação para o Estado de São Paulo. IAC. Campinas, Brazil. pp. 45-71. (Boletim téeniee, 100).

Embrapa - Empresa Brasileira de Pesquisa Agropecuária. 2013. Sistema brasileiro de classificação de solos. 3a ed. Rio de Janeiro, Brasil. Embrapa. 353 p.

Ernani, P.R.; Bayer, C.; Almeida, J.A.

2007. Mobilidade vertical de cátions influenciada pelo método de aplicação de cloreto de potássio em solos com carga variável. Revista Brasileira de Ciência do Solo, 31 (2): 393-402.

Ferreira, D.F.

2011. SISVAR: A computer statistical analysis system. Ciência e Agrotecnologia, 35 (6): 1039-1042.

Fraga, T.I.; Genro Junior, S.A.; Inda, A.V.; Anghinoni, I. 2009. Suprimento de potássio e mineralogia de solos de várzea sob cultivos sucessivos de arroz irrigado. Revista Brasileira de Ciência do Solo, 33 (3): 497-506.
Gazola, R.N.; Buzetti, S.; Dinalli, R.P.; Teixeira Filho, M.C.M.; Celestrino, T.S.

2013. Efeito residual da aplicação de fosfato monoamônio revestido por diferentes polímeros na cultura de milho. Revista Ceres, 60 (6): 876-884.

Gommers, A.; Thiry, Y.; Delvaux, B.

2005. Rhizospheric mobilization and plant uptake of radiocesium from weathered soils: I. Influence of potassium depletion. Journal of Environmental Quality, 34 (6): 2167-2173, 2005.

Guareschi, R.F.; Gazolla, P.R.; Perin, A.; Santini, J.M.K. 2011. Adubação antecipada na cultura da soja com superfosfato triplo e cloreto de potássio revestidos por polímeros. Ciência e Agrotecnologia, 35 (4): 643-648.

James, A.E.; Sojka, R.E.

2008. Matrix based fertilizers reduce nitrogen and phosphorus leaching in three soils, Journal of Environmental Management, 87 (3): 364-372, 2008.

Jarosiewicz, A.; Tomaszewska, M.

2003. Controlled-release NPK fertilizer encapsulated by polymeric membranes. Journal of Agricultural and Food Chemistry, 51 (2): 413-417.

Kaminski, J.; Brunetto, G.; Moterle, D.F.; Rheinheimer, D.S. 2007. Depleção de formas de potássio do solo afetada por cultivos sucessivos. Revista Brasileira de Ciência do Solo, 31 (5): 1003-1010.

Leal, A.J.F., Valderrama, M.; Kaneko, F.H.; Leal, U.A.S.;

Perin, A.; Luchese, K.U. de O.

2015. Produtividade da soja de acordo com diferentes doses de cloreto de potássio revestido ou não com polímeros. Global Science and Technology, 8 (1): 19-30.

Malavolta, E.; Vitti, G.C.; Oliveira, A.S.

1997. Avaliação do estado nutricional das plantas: Princípios e aplicações. 2a ed. . Piracicaba, Brasil. Potafos, 319 p.

Ni, B.L.; Liu, M.Z.; Lü, S.Y.

2009. Multifunctional slow-release urea fertilizer from ethylcellulose and superabsorbent coated formulations. Chemical Engineering Journal, 155 (3): 892-898. 
Raij, B. van; Andrade, J.C.; Cantarella, H.; Quaggio, J.A. 2001. Análise química para avaliação da fertilidade de solos tropicais. Campinas, Brasil. IAC. 285 p.

Rodrigues, M.A.C.; Buzetti, S.; Maestrelo, P.R.; Lino, A.C.M.; Teixeira Filho, M.C.M.; Andreotti, M.; Garcia, C.M.P.

2013. Cloreto de potássio revestido em efeito residual no feijoeiro de inverno irrigado na região de cerrado. Semina: Ciências Agrárias, 34 (3): 1011-1022.

Rodrigues, M.A.C.; Buzetti, S.; Teixeira Filho, M.C.M.;

Garcia, C.M.P.; Andreotti, M.

2014. Adubação com $\mathrm{KCl}$ revestido na cultura do milho no Cerrado. Revista Brasileira de Engenharia Agrícola e Ambiental, 18 (2): 127-133.

Rosolem, C.A.; Vicentini, J.P.T.M.M.; Steiner, F.

2012. Suprimento de potássio em função da adubação potássica residual em um Latossolo Vermelho do cerrado. Revista Brasileira de Ciência do Solo, 36 (5): 1507-1515.
Valderrama, M.; Buzetti, S.; Benett, C.G.S.; Andreotti, M.; Teixeira Filho, M.C.M.

2011. Fontes e doses de NPK em milho irrigado sob plantio direto. Pesquisa Agropecuária Tropical, 41 (2): 254-263.

Werle, R., Garcia, R.A.; Rosolem, C.A.

2008. Lixiviação de potássio em função da textura e da disponibilidade do nutriente no solo. Revista Brasileira de Ciência do Solo, 32 (6): 2297-2305.

Wu, L.; Liu, M.

2008. Preparation and properties of chitosancoated NPK compound fertilizer with controlled-release and waterretention. Carbohydrate Polymers, 72 (2): 240-247, 2008.

Xie, L.; Liu, M.; Ni, B.; Zhang, X.; Wang, Y.

2011. Slowrelease nitrogen and boron fertilizer from a functional superabsorbent formulation based on wheat straw and attapulgite. Chemical Engineering Journal, 167 (1): 342-348. 